\title{
THE EFFECT OF ORGANIZATIONAL CULTURE ON EMPLOYEE PERFORMANCE AT ALFAMIDI PROSPERITY MINIMARKET OUTLET SOPPENG
}

\author{
by \\ Andi Asrijal ${ }^{1}$, Rusnaedi ${ }^{2}$ Irmawati $^{3}$ \\ 1,2,3 Puangrimaggalatung College of Administrative Sciences \\ Email: ${ }^{1}$ andiasri1397@ gmail.com, ${ }^{2}$ rusnaediedi21@ gmail.com, ${ }^{3}$ irmaw0213@ gmail.com
}

\begin{tabular}{l}
\hline Article Info \\
\hline Article History: \\
Received:13-10-21 \\
Revised: $16-11-21$ \\
Accepted: $24-11-2021$
\end{tabular}

\section{Keywords:}

Organizational Culture,

Employee Performance, Organizational Commitment

\begin{abstract}
The performance of an organization can be determined by the existence of a good organizational culture that exists within an organization. This work culture will not just appear, but must be pursued in earnest through a controlled process involving a controlled process involving all Human Resources (HR) in a set of systems, tools and supporting techniques. The objectives of the research carried out by the Alfamidi Prosperity Minimarket Outlet Soppeng are: to find out the description of organizational culture and employee performance at the Alfamidi Prosperity Soppeng Minimarket Outlet, Soppeng Regency. To answer these questions, the stages of the research method were used, starting from the literature review and field study, proposal preparation, testing the validity and reliability of the instrument, data collection, analysis and discussion. The data analysis used is descriptive quantitative. The results showed that the work culture of the employees at the Alfamidi Prosperity Minimarket Outlet Soppeng was high, as well as the employee performance at the Alfamidi Prosperity Soppeng Minimarket Outlet showed that the employee's performance was very good in achieving organizational goals.
\end{abstract}

Thisisan open accessarticleundertheCC BY-SAlicense.

CorrespondingAuthor:

Andi Asrijal

Puangrimaggalatung College of Administrative Sciences

Email: andiasri1397@gmail.com

\section{INTRODUCTION}

Culture is something that must exist in a human group or organization. We also live in a society that has a culture that is different from the culture of other societies. The culture that we have consciously or not will affect our attitudes and behavior in various aspects of life.

Culture is the result of thought and then carried out in life for both individuals and as members of society. The results of these thoughts can be in the form of knowledge, belief, art, values and morals obtained from human interaction with the environment, both interactions with nature and with other humans in community life.

This work culture will not just appear, but must be pursued in earnest through a controlled process involving a controlled process involving all Human Resources (HR) in a set of systems, tools and supporting techniques. Work culture is a philosophy based on a view of life as values that become traits, habits and driving forces, entrenched in the life of a community or organization, then reflected in attitudes into behaviors, beliefs, ideals, opinions and actions that manifest as "Work or "work".

For this reason, the company has carried out many activities such as providing education and training for employees, increasing salaries and benefits, giving awards, punishments and so on with the hope of increasing employee performance. However, the increase in the performance of employees has not shown satisfactory results. Although in some areas employee performance has been carried out well, there are still many areas where employees violate regulations in carrying out their duties and functions as customer servants.

The phenomenon that exists in the field is the problem of employee organizational culture which in general seems to be still low which ultimately results in low performance as well. For example, most employees make mistakes in recording and serving customers. Then many people complain about the difficulty of getting services from employees. Whereas the function of the company/organization is none other than to serve the interests of the needs of 
the wider community. This condition can be regarded as a violation of work discipline, because the employees do not act or behave in accordance with the rules and procedures set by the organization. Employees absent from work during office hours or after national holidays are still a problem at various Alfamidi minimarket outlets.

Ashley Montagu and Christopher Dawson (in Supriadi, Gering. Guno, Tri 2006:4), define culture as a way of life, namely a certain way of life that radiates a certain identity from a nation.

According to Koentjaraningrat (in Supriadi, Gering. Guno, Tri 2006:4), culture is "the whole system of ideas, actions and the results of human work in the context of community life which belongs to humans by means of learning".

Organizational culture is a shared perception shared by all members of the organization. Robbins (2001) states that organizational culture refers to a system of shared meaning held by members that distinguishes the organization from other organizations.

Furthermore, David (2004) states that organizational culture is a pattern of behavior developed by an organization that it learns when experiencing problems of external adaptation and internal integration, which has proven to be good enough to be validated and taught to new members as a way to realize, think and feel.

In Mangkunegara (2006: 9) some define employee performance as follows:

1) Kusriyanto states that employee performance is a comparison of the results achieved with the participation of the workforce per unit of time (usually hourly).

2) Cardosa states that Employee performance is an expression like output, efficiency and effectiveness are often required with productivity.

3) Mengkunegara states that employee performance is the result of work in quality and quantity achieved by an employee in carrying out his duties in accordance with the responsibilities given to him.

In knowing the high and low performance of a person, a management tool is needed to improve the quality of decision making and accountability. Measures of performance or work performance in general which are then translated into basic behavioral assessments according to Hady Sutrisno (2009: 167), namely:

1. Work result

2. Job knowledge

3. Initiative

4. Mental skills

5. Discipline

6. Attitude

Minimarket customer service needs to understand the character, habits and expectations of the targeted consumers, here are some strategic efforts that must or can be applied in minimarket customer service.

According to Uma Sekaran (in Pasolong, Harbani 2005: 49) suggests that, the framework of thinking is a conceptual model of how theory relates to various factors that have been identified as urgent problems. A good framework will explain theoretically the rules between the variables to be studied. From the description above, it is concluded that the framework of thought in this study can be seen in the following:

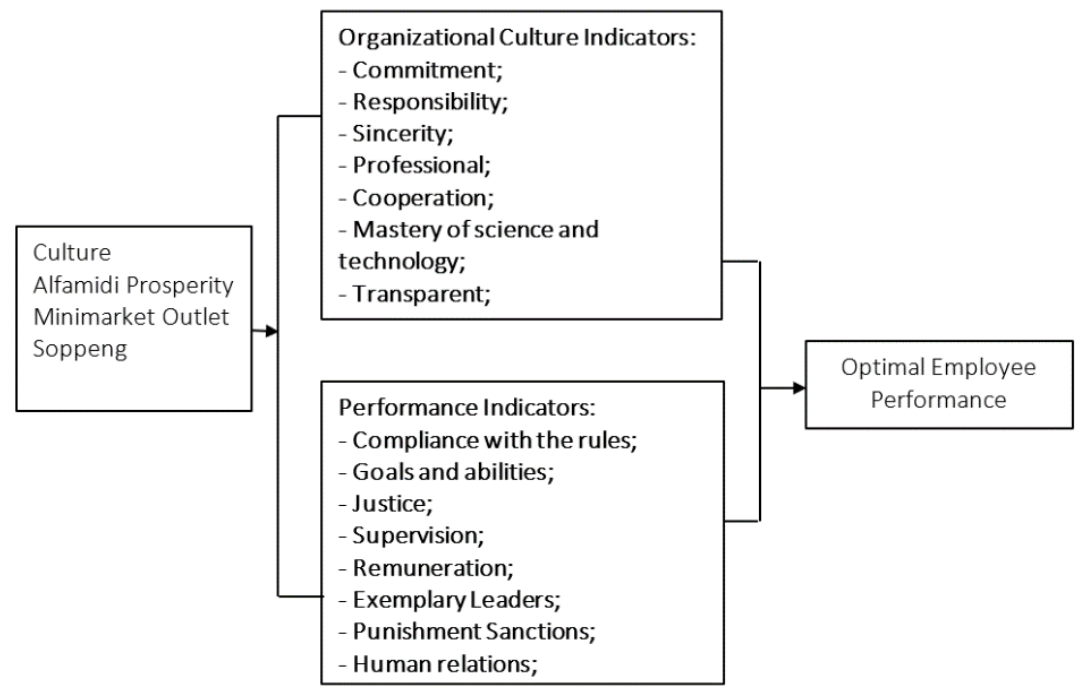

Figure 1. Conceptual Framework 
International Journal of Social Science (IJSS)

Vol.1 Issue.4 December 2021, pp: 385-392

ISSN: 2798-3463 (Printed) | 2798-4079 (Online)

2. METHOD

This research is a quantitative descriptive research conducted to take samples. Based on the probability level in sampling, this research is a research with probability sampling technique, where each sample has the opportunity to be selected.

The primary data from this research are the people who are the object of this research, namely all staff on duty at the Alfamidi Prosperity Soppeng outlet.

the determination of the sample using probability sampling which seeks to provide equal opportunities for the population to be sampled. The technique used is a simple random sample, meaning that each unit in the population is given the same opportunity to be selected because it is relatively homogeneous.

for the purposes of this study used an instrument, namely a questionnaire. This instrument is a non-test instrument that is used only to measure a person's ability, attitude or perception of the questions asked about the variables to be measured, namely:

culture and performance. while to answer the above problems used descriptive statistical analysis. The analysis begins with data collection and continues until all the components of the questionnaire have been filled in.

\section{RESEARCH RESULTS AND DISCUSSION}

The results of the research that has been carried out by the Alfamidi Kemakmuran Soppeng Minimarket Outlet by distributing questionnaires to the respondents as many as 10 (ten) employees as samples in this study.

To obtain a clear picture of the data obtained by the questionnaire, below is the data presented in the distribution tables as follows:

Table 1. Distribution of respondents' answers regarding the commitment of Alfamidi Prosperity Minimarket Outlet Soppeng

\begin{tabular}{cccc}
\hline Category & Score & Frequency (f) & Percentage (\%) \\
\hline Very capable & 5 & 6 & 60.00 \\
Capable & 4 & 3 & 30.00 \\
quite capable & 3 & 1 & 10.00 \\
Less fortunate & 2 & 0 & 0 \\
Not capable & 1 & 0 & 0
\end{tabular}

Amount $10 \quad 100$

Source: Questionnaire 2021

With the commitment among members of the organization to each other, it becomes the capital in realizing the goals of the organization.

Based on the table above, it shows that the respondents who answered very capable and had a commitment were 6 people (60.00\%), who answered capable of 3 people (30.00\%), respondents who answered quite capable of 1 person $(10.00 \%)$, and there are no respondents who answered less able and unable.

Table 2. The distribution of respondents' answers is always serious and full of responsibility in carrying out work at the Alfamidi Prosperity Soppeng Minimarket Outlet

\begin{tabular}{cccc}
\hline Category & Score & Frequency (f) & Percentage (\%) \\
\hline Always & 5 & 3 & 30.00 \\
Often & 4 & 5 & 50.00 \\
Sometimes & 3 & 2 & 20.00 \\
Seldom & 2 & 0 & 0 \\
Never & 1 & 0 & 0
\end{tabular}

Amount

10

100

Source: 2021 questionnaire 
In carrying out a job we are required to always mean it with a full sense of responsibility so that the goals of the organization can be achieved properly.

Based on table 2 above, the respondents who answered often were serious in carrying out their work as many as 5 people (50.00), who answered always 3 people (30.00\%), then 2 people who answered sometimes (20.00\%) ) and respondents who answered rarely and never did not exist.

Table 3. The distribution of respondents' answers in carrying out work is always done with sincerity at the Alfamidi Prosperity Soppeng Minimarket Outlet

\begin{tabular}{cccc}
\hline Category & Score & Frequency (f) & Percentage (\%) \\
\hline Always & 5 & 5 & 50.00 \\
Often & 4 & 4 & 40.00 \\
Sometimes & 3 & 1 & 10.00 \\
Seldom & 2 & 0 & 0 \\
Never & 1 & 0 & 0 \\
\hline Amount & & 10 & 100
\end{tabular}

Source: Questionnaire 2021

A civil servant and a public servant are always required to always do work sincerely with full sincerity without complaining and demanding compensation.

Based on the data in table 3 above, the respondents who answered that they always carried out their work with sincerity were 5 people $(50.00 \%)$, who answered often 4 people $(40.00 \%)$, respondents who answered sometimes 1 person (10, $00 \%$ ), none of the respondents answered rarely and never.

Table 4. The distribution of respondents' answers in carrying out work is always carried out professionally at the Alfamidi Prosperity Soppeng Minimarket Outlet

\begin{tabular}{cccc}
\hline Category & Score & Frequency $(\mathrm{f})$ & Percentage $(\%)$ \\
\hline Always & 5 & 10 & 100.00 \\
Often & 4 & 0 & 0 \\
Sometimes & 3 & 0 & 0 \\
Seldom & 2 & 0 & 0 \\
Never & 1 & 0 & 0 \\
\hline Amount & & 10 & 100 \\
\hline
\end{tabular}

Source: Questionnaire 2021

To be able to say someone has the ability other than the level of education that is adjusted to the type of work, employees still need the ability to master or recognize a field that is charged to the employee. Employees are required to have innovation and expertise and always try to improve their abilities.

Based on the data in the table above, all respondents answered that they always carried out their work professionally as many as 10 people (100.00\%), and there were no respondents who said sometimes, rarely and never.

Table 5. Distribution of respondents' answers about the encouragement to cooperate with other employees at the Alfamidi Kemakmuran Soppeng Minimarket Outlet

\begin{tabular}{cccc}
\hline Category & Score & Frequency (f) & Percentage (\%) \\
\hline Always & 5 & 7 & 70.00 \\
Often & 4 & 3 & 30.00 \\
Sometimes & 3 & 0 & 0 \\
Seldom & 2 & 0 & 0 \\
Never & 1 & 0 & 0
\end{tabular}

\begin{tabular}{lcc}
\hline Amount & 10 & 100 \\
\hline
\end{tabular}

Source: 2021 questionnaire

Togetherness and cohesiveness in carrying out something will speed up the completion of a job. Because we are required to cooperate with each other in all things so that the goals of the organization can be achieved.

Based on the data in the table above, respondents who answered that they often collaborated with other people in carrying out their work were 3 people $(30.00 \%)$, who answered always 7 people $(70.00 \%)$ and no respondents answered sometimes, rarely. and never. 
International Journal of Social Science (IJSS)

Vol.1 Issue.4 December 2021, pp: 385-392

ISSN: 2798-3463 (Printed) | 2798-4079 (Online)

Table 6. Distribution of respondents' answers about the ability of employees to carry out work that follows the development of science and technology at the Alfamidi Prosperity Soppeng Minimarket Outlet

\begin{tabular}{cccc}
\hline Category & Score & Frequency (f) & Percentage (\%) \\
\hline Very capable & 5 & 7 & 70.00 \\
capable & 4 & 2 & 20.00 \\
quite capable & 3 & 1 & 10.00 \\
less fortunate & 2 & 0 & 0 \\
Not capable & 1 & 0 & 0
\end{tabular}

\begin{tabular}{lll}
\hline Amount & 10 & 100
\end{tabular}

Source: Questionnaire 2021

The development of science and technology (IPTEK) has a very broad impact on people's lives. It can be seen that all work was done manually now all work can be completed using a computer. Therefore, as state servants and public servants, we are required to be able to use sophisticated technological tools so that efficiency, effectiveness and productivity can be achieved.

Based on the data in the table above. Respondents who are able to carry out work by following the development of science and technology (IPTEK) as many as 2 people $(20.00 \%)$, respondents who answered very capable as many as 7 people $(70.00 \%)$ who answered quite capable 1 person $(10.00 \%)$ and there are no respondents who answered less able and unable.

Table 7. Distribution of respondents' answers regarding work that is always reported transparently about the results obtained to the leadership at the Alfamidi Prosperity Soppeng Minimarket Outlet

\begin{tabular}{cccc}
\hline Category & Score & Frequency (f) & Percentage (\%) \\
\hline Always & 5 & 10 & 100.00 \\
Often & 4 & 0 & 0 \\
Sometimes & 3 & 0 & 0 \\
Seldom & 2 & 0 & 0 \\
Never & 1 & 0 & 0
\end{tabular}

\begin{tabular}{lll}
\hline Amount & 10 & 100
\end{tabular}

Source: Questionnaire 2021

A good employee, when carrying out work, always reports the results to the leadership of the right and correct data or information openly without anything being hidden.

Based on the data in the table above, it shows that all respondents who answered always reported transparently the results achieved to the leadership as many as 10 people (100.00\%).

Table 8. Distribution of respondents' answers regarding firmness in carrying out a job so as not to harm themselves, others and the Alfamidi Prosperity Soppeng Minimarket Outlet Organization
Category
Score
Frequency (f)
Percentage (\%)

\begin{tabular}{cccc}
\hline Very capable & 5 & 8 & 80.00 \\
capable & 4 & 2 & 20.00 \\
quite capable & 3 & 0 & 0 \\
less fortunate & 2 & 0 & 0 \\
Not capable & 1 & 0 & 0
\end{tabular}




$\begin{array}{lll}\text { Amount } & 10 & 100\end{array}$

Source: Questionnaire 2021

In carrying out a job we are required to be firm without being influenced by other people who can harm ourselves and the organization.

From the data in the table above, it shows that respondents who are very able to be assertive in carrying out work are 8 people $(80.00 \%)$, respondents who answered that they were able to 2 people (20.00\%), and no respondents answered enough, less able and unable.

In this study, to measure work culture indicators of commitment, responsibility, sincerity, professionalism, cooperation, mastery of science and technology, transparency and firmness were used. The work culture of employees at the Alfamidi Prosperity Soppeng Minimarket Outlet is in the very high category, this can be seen from the distribution of respondents' answers that have been given. The success of an organization is largely determined by various factors, one of which is the work culture factor. Where work culture is the norms or values that direct the behavior of members of the organization.

In addition to cohesiveness and togetherness, we are also required to have innovation and expertise and always try to improve our abilities by following the development of science and technology (IPTEK). Therefore, as state servants and public servants, we are required to be able to use sophisticated technological tools so as to increase efficiency, effectiveness, and productivity. A good employee when carrying out work always reports the results to the leadership of the right and correct data or information openly without anything being hidden so that the goals of the organization can be achieved properly.

Performance is the result of work achieved by a person or group of people in an organization in achieving organizational goals in a certain period of time, the success of an organization is when the performance of its employees has reached the maximum level.

In this case, it shows that the performance of the employees at the Alfamidi Prosperity Soppeng Minimarket Outlet is very good, this is in accordance with the respondents' answers that have been given. The performance of Alfamidi Prosperity Soppeng Minimarket Outlet employees can be measured by the following indicators:

Table 9. Distribution of respondents' answers about the ability to obey, implement and fully implement the rules awareness and responsibility

\begin{tabular}{cccc}
\hline Category & Score & Frequency (f) & Percentage (\%) \\
\hline Always & 5 & 8 & 80.00 \\
Often & 4 & 2 & 20.00 \\
Sometimes & 3 & 0 & 0 \\
Seldom & 2 & 0 & 0 \\
Never & 1 & 0 & 0 \\
& & & 100 \\
\hline Amount & & 10 & \\
\hline
\end{tabular}

Source: Questionnaire 2021

As state servants and public servants, civil servants are required to obey, implement and practice the rules with full awareness, seriously and with full responsibility. Employees who have good performance will certainly comply with the regulations contained in the organization where they work.

Based on the data in the table above, respondents who answered that they always obeyed the rules in carrying out their duties at the Alfamidi Kemakmuran Soppeng Minimarket Outlet, there were 8 people (80.00\%), who answered often 2 people $(20.00 \%)$, and no one answered sometimes. sometimes, rarely and never. 
International Journal of Social Science (IJSS)

Vol.1 Issue.4 December 2021, pp: 385-392

ISSN: 2798-3463 (Printed) | 2798-4079 (Online)

Table 10. The distribution of respondents' answers regarding the work assigned is in accordance with their skills and abilities

\begin{tabular}{cccc}
\hline Category & Score & Frequency (f) & Percentage (\%) \\
\hline Always & 5 & 6 & 60.00 \\
Often & 4 & 3 & 30.00 \\
Sometimes & 3 & 1 & 10.00 \\
Seldom & 2 & 0 & 0 \\
Never & 1 & 0 & 0
\end{tabular}

\begin{tabular}{lll}
\hline Amount & 10 & 100
\end{tabular}

Source: Questionnaire 2021

In general, an employee's work performance is influenced by the skills, skills, experience, and abilities of employees in carrying out their duties and functions. An employee who does not have the ability to complete his duties will certainly not have good work performance. And in the end the goals of the organization will not be achieved.

Based on the table above, it is known that the respondents who answered always were 6 people $(60.00 \%)$, respondents who answered often were 3 people $(30.00 \%)$, 1 person (10.00\%) answered sometimes, none respondents who answered rarely and never.

Table 11. Distribution of respondents' answers about the courage to bear risks arising from the work assigned

\begin{tabular}{cccc}
\hline Category & Score & Frequency (f) & Percentage (\%) \\
\hline Very capable & 5 & 8 & 80.00 \\
capable & 4 & 2 & 20.00 \\
quite capable & 3 & 0 & 0 \\
less fortunate & 2 & 0 & 0 \\
Not capable & 1 & 0 & 0
\end{tabular}

\begin{tabular}{lll}
\hline Amount & 10 & 100
\end{tabular}

Source: Questionnaire 2021

Every job requires responsibility, care and concern. Employees who are able to have responsibility and care for their work also dare to take all the risks posed by their work.

Based on the data in the table above, the respondents who answered very well were 8 people $(80.00 \%)$, and those who answered that they were able to bear the risks posed by their work were 2 people $(20.00 \%)$, there were no respondents who answered that they were quite capable, underprivileged and incapable.

Table 12. Distribution of respondents' answers about the ability to comply with the applicable regulations at the Alfamidi Prosperity Soppeng Minimarket Outlet

\begin{tabular}{cccc}
\hline Category & Score & Frequency (f) & Percentage (\%) \\
\hline Very capable & 5 & 7 & 70.00 \\
capable & 4 & 3 & 30.00 \\
quite capable & 3 & 0 & 0 \\
less fortunate & 2 & 0 & 0 \\
Not capable & 1 & 0 & 0
\end{tabular}

\begin{tabular}{lll}
\hline Amount & 10 & 100
\end{tabular}

Source: Questionnaire 2021

Discipline has meaning as an awareness effort to comply with organizational regulations and laws and regulations and other official regulations so that it will improve performance. 
From the table data above, respondents who answered that they were very able to obey the applicable regulations were 7 people $(70.00 \%)$, respondents who answered that they were able to 3 people $(30.00 \%)$, no respondents answered that sometimes they were less able, and Not capable.

Table 13. Distribution of respondents' answers regarding honesty in carrying out their duties and not abusing the authority given to him

\begin{tabular}{cccc}
\hline Category & Score & Frequency (f) & Percentage (\%) \\
\hline Always & 5 & 10 & 100.00 \\
Often & 4 & 0 & 0 \\
Sometimes & 3 & 0 & 0 \\
Seldom & 2 & 0 & 0 \\
Never & 1 & 0 & 0
\end{tabular}

\begin{tabular}{lll}
\hline Amount & 10 & 100
\end{tabular}

Source: Questionnaire 2021

Honest attitude towards work is very important to improve performance. Someone who is honest in carrying out his work and does not abuse the authority given to him, will get the full trust of his leadership.

Based on the data in the table above, it shows that all respondents who answered were always honest in carrying out their work as many as 10 people (100.00\%).

Table 14. Distribution of respondents' answers about the ability to cooperate with others in completing work

Category Score $\quad$ Frequency (f) Percentage (\%)

\begin{tabular}{cccc}
\hline Very capable & 5 & 8 & 80.00 \\
capable & 4 & 2 & 20.00 \\
quite capable & 3 & 0 & 0 \\
less fortunate & 2 & 0 & 0 \\
Not capable & 1 & 0 & 0
\end{tabular}

\begin{tabular}{lcc}
\hline Amount & 10 & 100 \\
\hline
\end{tabular}

Source: Questionnaire 2021

Cooperation is a mutually reinforcing relationship in carrying out work. Cooperation will be realized if it is based on a common understanding and active communication based on mutual dependence on one another.

Based on the data in the table above, it shows that the respondents who answered were very capable and able to cooperate with others in completing their work respectively 8 people $(80.00 \%)$, while those who answered were able to as many as $2(20.00 \%)$ people, not There are respondents who answered quite capable, less able and unable.

Table 15. Distribution of respondents' answers about the ability to convince others so that they can be mobilized to carry out their duties

\begin{tabular}{cccc}
\hline Category & Score & Frequency (f) & Percentage (\%) \\
\hline Very capable & 5 & 8 & 80.00 \\
capable & 4 & 2 & 20.00 \\
quite capable & 3 & 0 & 0 \\
less fortunate & 2 & 0 & 0 \\
Not capable & 1 & 0 & 0
\end{tabular}

\begin{tabular}{lcc}
\hline Amount & 10 & 100 \\
\hline
\end{tabular}

Source: 2017 Questionnaire 
International Journal of Social Science (IJSS)

Vol.1 Issue.4 December 2021, pp: 385-392

ISSN: 2798-3463 (Printed) | 2798-4079 (Online)

DOI: https://doi.org/10.53625/ijss.v1i4.741

According to Terry and Franklin (in Amirullah, Budiyono 2004:245) defines leadership as a relationship in which a person (leader) influences others to cooperate in carrying out interrelated tasks in order to achieve the desired goals of the leader and/or group. Meanwhile, according to Davis (in Amirullah, Budiyono 2004:245) defines leadership as the ability to persuade others to achieve the goals that have been set.

Based on the table above, it can be illustrated that the respondents who are able to influence other people are 2 people (20.00\%), respondents who answered very well 8 people (80.00\%), no respondents answered quite capable, less able and unable.

Work performance assessed by the eight indicators mentioned above shows that employees at the Alfamidi Prosperity Soppeng Minimarket Outlet always obey the regulations. Of course, as state servants and civil servants, we are always required to obey, implement and practice the rules with full awareness, seriously and with full responsibility. Employees who have good performance will certainly comply with the regulations contained in the organization where they work.

And in general the work performance of an employee is influenced by the skills, skills, experience, and abilities of employees in carrying out their duties and functions. An employee who does not have the ability to complete his duties will certainly not have good work performance. And in the end the goals and organization will not be achieved. Honest attitude towards work is very important to improve performance.

\section{REFERENCES}

[1] Amirullah. Budiono, Haris. 2004. Introduction to Management. Yogyakarta: Graha Ilmu.

[2] Andy's Light. 2019. Administrative Research Methodology. STIA Prima Bone Textbook.

[3] David, 2004. Organizational Culture. Management and Organization. Journal online system. Jakarta

[4] Handoko, T. Hani. 2009. Personnel Management and Human Resources. Yogyakarta: BPFE.

[5] Hasibuan, Malayu. SP 2003. Human Resource Management. Jakarta : PT. Earth Literature.

[6] Jeddawi, Murtir. 2010. PNS Career at Crossroads; A reflection on employee policies in the Era of Regional Autonomy. Yogyakarta: Science Gallery.

[7] Mangkunegara, Anwar Prabu. 2005. Organizational Cultural Behavior. Bandung: PT. Rafika Aditama.

[8] Norman Barry, 2010. The Concept of Influence . Organization and Management. Son Earth

[9] Pasolong, harbani, 2005. Community Service. Journal online system. grammar. Jakarta

[10] Perucci and hamby in Tampubolon. 2004. Definition of Culture. Son Earth. Jakarta

[11] Poewadarminta. WJS 2004. General Indonesian Dictionary. Jakarta: Balai Pustaka.

[12] Prasetyo, Bambang. MJLina. 2010. Quantitative Research Methods. Jakarta: Rajawali Press.

[13] Sunyoto. Danang. 2009. Regression Analysis and Hypothesis Testing. Yogyakarta: Media Pressindo.

[14] Supriadi, Gering, Guno, Tri. 2006. Understanding Culture. Family Sociology. Jakarta Media

[15] Soekanto, Soerjono. 2000. Sociology as an Introduction . Jakarta: Raja Grafindo Persada.

[16] Siagian, Sondang P. 2009. Human Resource Management. Jakarta: PT. Earth Literature.

[17] Robbins, 2001. Understanding Culture. Organization and Management. Holy mountain. Jakarta

[18] The Liang Gie. 2001. Modern Office Administration. Yogyakarta: Liberty.

[19] Tika, Pabundu. 2006. Organizational Culture and Company Performance Improvement. Jakarta: PT. Earth Literature.

[20] Uwe Becker, 2010. The Concept of Influence. Journal online system. Holy mountain. Jakarta

[21] Wiryanto, 2010. The Concept of Influence . Print edition II. Holy mountain. Jakarta 
